\title{
Клінічна ефективність корекції ендотеліальної дисфункції судин у пери- та післяопераційний періоди в паціентів із гострим коронарним синдромом у поєднанні з облітеруючим атеросклерозом нижніх кінцівок
}

\begin{abstract}
Мета роботи: вивчити ефективність інтервенційного та медикаментозного лікування хворих на гострий коронарний синдром без підйому сегмента ST у поєднанні з облітеруючим атеросклерозом магістральних судин на стадії критичної ішемії нижніх кінцівок та високим ризиком розвитку кардіальних ускладнень на стаціонарному етапі лікування.

Матеріали і методи. У дослідженні брали участь 54 хворих на гострий коронарний синдром без підйому ST в поєднанні з облітеруючим атеросклерозом з III-IV стадіями хронічної ішемії за класифікацією Б. В. Покровського або Fontaine, що відповідає критичній ішемії 4, 5 і 6 категорій (grade II-III) за Rutherford (ESC, 2017), яких залежно від вибраної тактики лікування розподілили в 2 групи: основна дослідна група - 34 хворі, які, окрім стандартного лікування ГКС, додатково внутрішньовенно отримали 4,2 г L-аргініну та 2,0 г L-карнітину у формі розчину для інфузій по 100 мл один раз на добу курсом 7 днів. Одне вливання препарату проводили перед інтервенційним втручанням. Контрольна група - 20 пацієнтів, яким також проведено ургентну балонну ангіопластику та стентування інфаркт-залежної коронарної артерії, але хворі цієї групи отримували лише стандартне протокольне лікування.

Окрім загальноклінічних, інструментальних та лабораторних методів (загальний аналіз крові, МВ фракції креатинфосфокінази (КФК-МВ), тропоніну Т, насичення артеріальної крові киснем (SpO2 ), ЕКГ у 12 стандартних відведеннях тощо), проводили визначення функціонального стану судинного ендотелію за концентрацією ендотеліну-1(ЕT-1) в плазмі крові (за допомогою імуноферментного набору фірми “Аmersham Pharmacia Biotech”) та вмістом стабільних метаболітів NO, які визначали за реакцією з реактивом Гріса.

Результати досліджень та їх обговорення. У вихідному стані у хворих на ГКСбпSТ в поєднанні з ОАНК встановлено виражені порушення мікроциркуляції та ендотеліальної функції та їх додаткове погіршення в пери- і післяопераційному періодах після перкутанного коронарного втручання, що супроводжується розвитком реперфузійного синдрому з різною тривалістю та виразністю лівошлуночкової недостатності та порушень ритму і провідності. Під впливом стандартного медикаментозного лікування у хворих контрольної групи встановлено наявність резистентних до лікування суправентрикулярних та шлуночкових екстрасистол. Водночас у хворих на ГКСбпSТ у поєднанні з ОАНК дослідної групи під впливом комплексного медикаментозного лікування з включенням L-аргініну та L-карнітину вже на другу добу спостереження встановлено суттєве зменшення частоти порушень ритму і провідності, а після курсу лікування в коморбідних хворих дослідної групи частота порушень ритму і провідності знизилась на 53,1% і проявів гострої серцевої недостатності на 44,2%.

Отриманий результат обгрунтовує доцільність впровадження запропонованої цитопротекторної антиоксидантної терапії в передопераційному періоді для запобігання проявам реперфузійного синдрому та їі продовження в післяопераційному періоді для стабілізації клінічного стану пацієнтів та вторинної профілактики ускладнень.
\end{abstract}

Ключові слова: гострий коронарний синдром; облітеруючий атеросклероз нижніх концівок; ендотелін; оксид азоту; черезшкірне коронарне втручання; реперфузійні ускладнення; аргінін-карнітиновий комплекс.

Постановка проблеми і аналіз останніх досліджень та публікацій. Захворюваність та смертність від серцево-судинних захворювань є проблемою номер один в усьому світі, оскільки за даними ВООЗ щорічно реєструють понад 17 мільйонів, а в Європі близько 4 млн смертей внаслідок кардіоваскулярної патології, що становить біля 42-47 \% всіх випадків смерті [15]. В останні роки в Україні смертність від хвороб системи кровообігу зростає і займає перше місце в структурі причин смертності (68 \%) та первинного виходу на інвалідність серед працездатного населення (22,8 \%), що становить велику медико-соціальну та економічну проблему $[1,5]$, оскільки щорічно діагностують понад
50 тис. нових випадків інфаркту міокарда, а рівень смертності за останнє десятиліття склав - 13,9 \%. Суттєвий внесок у цю негативну тенденцію вносить захворюваність на різні типи гострого коронарного синдрому (ГКС), особливо ГКС без підйому сегмента ST (ГКСбпST), які, за даними багатоцентрових досліджень, щорічно є причиною великого числа госпіталізацій (близько 70 \% від всіх хворих на ГКС) і летальних наслідків - 1820 \% впродовж перших двох років [5].

Основним патогенетичним механізмом розвитку ГКС є атеросклероз та атеротромбоз. Однак атеросклероз - це системне захворювання, яке вражає різні відділи артеріальної системи і час- 
тота виявлення цих комбінованих уражень у популяції варіює від 18 до 54 \%, а серед хворих на IXC досягає 90 \% [4]. Особливу групу серед таких пацієнтів складають хворі з ГКСбпST у поєднанні з ОАНК на стадії критичної ішемії, у яких ризик розвитку ускладнень і несприятливих наслідків (летального IM, ГСН, життєво небезпечних аритмій, гангрени) суттєво вище, ніж у пацієнтів із середнім та низьким ризиком [8]. Облітеруючий атеросклероз магістральних периферичних судин діагностують у понад 20 \% випадків усієї серцево-судинної патології, що складає близько 3 \% загальної кількості населення [12]. При цьому встановлено, що відсоток 5-річного виживання у хворих із коронарним атеросклерозом становить 80-85 \%, а при МФА цей показник не перевищує 50 \% [8]. Даний факт особливо важливий для пацієнтів високого ризику, якими є хворі 3 ГКС та критичною ішемією нижніх кінцівок внаслідок облітеруючого атеросклерозу [14], у яких несприятливий ранній прогноз асоціюється з тяжчим, ускладненим перебігом хвороби, обмеженням проведення інвазивних коронарних втручань, протипоказаннями до проведення активних кардіореабілітаційних заходів $[7,10]$.

Саме обмеження можливості застосування високоефективних ранніх інвазивних коронарних втручань у хворих на гострий коронарний синдром (ГКС) у поєднанні з МФА визначає тактику активного вивчення ролі активності вільнорадикального окиснення ліпідів, неспецифічного низькоінтенсивного судинного запалення та ендотеліальної дисфункції в патогенезі даної коморбідної патології, розвитку окремих її ускладнень [2, $3,14]$ та розробці шляхів корекції цих патологічних процесів із метою підготовки до операційних втручань та профілактики ускладнень в периопераційному та післяопераційному періодах.

Серед взаємообтяжувальних патогенетичних факторів даних коморбідних станів останнім часом ключову роль надають таким чинникам, як системне низькоінтенсивне запалення та пероксидний стрес, які спричиняють порушення ендотеліальної функції судин і лежать в основі порушення енергетичного метаболізму та ішемічного пошкодження як кардіоміоцитів, так і тканин нижніх кінцівок.

Вказаний патогенетичний механізм розвитку ускладнень та прогресування ГКС (IM) і критичної ішемії нижніх кінцівок передбачає можливість медикаментозного впливу на ці патологічні процеси метаболічної та цитопротекторної терапії.

Мета роботи: вивчити ефективність інтервенційного та медикаментозного лікування хворих на гострий коронарний синдромом без підйому сегмента ST у поєднанні з облітеруючим атеросклерозом магістральних судин на стадії критичної ішемії нижніх кінцівок та високим ризиком розвитку кардіальних ускладнень на стаціонарному етапі лікування.

Матеріали і методи. У дослідженні брали участь 54 хворі на гострий коронарний синдром без підйому ST в поєднанні з облітеруючим атеросклерозом із III-IV стадіями хронічної ішемії за класифікацією Б. В. Покровського або Fontaine [14], що відповідає критичній ішемії 4, 5 і 6 категорій (grade II-III) за Rutherford (ESC, 2017), яких залежно від вибраної тактики лікування розподілили в 2 групи: основна дослідна група - 34 хворі на ГКСбпST та облітеруючий атеросклероз і критичну ішемію нижніх кінцівок, які, окрім стандартного лікування ГКС згідно з Уніфікованими протоколами МОЗ України, отримали модифіковане лікування із додатковим включенням 4,2 г L-аргініну та 2,0 г L-карнітину у формі розчину для інфузій по 100 мл один раз на добу курсом 7 днів внутрішньовенно. Одне внутрішньовенне вливання препарату проводили перед інтервенційним втручанням.

Контрольну групу склали 20 пацієнтів, яким також проведено ургентну балонну ангіопластику та стентування інфаркт-залежної коронарної артерії, але хворі цієї групи отримували лише стандартне протокольне лікування.

Серед хворих переважали чоловіки (87,5 \%) працездатного віку, який становив в середньому $(57,54 \pm 8,02)$ року. Діагноз гострого коронарного синдрому верифікували згідно з рекомендаціями ESC (2017) при наявності типового ангінозного нападу, швидкої динаміки змін кривої електрокардіограми (зубця Т та сегмента ST) і відсутності ознак резорбтивно-некротичного синдрому та підтверджували результатами ургентної коронароангіографії. Підтвердження діагнозу облітеруючого атеросклерозу магістральних судин нижніх кінцівок проводили за допомогою клініко-лабораторних (вираженість больового синдрому, відсутність пульсації артерій на всіх рівнях нижньої кінцівки, гіпотрофії м'язів гомілки і стегна, наявності трофічних змін у ділянці пальців стоп (13 спостережень), виразок на стопі (6 спостережень), виявленні багряного відтінку дистальних відділів гомілки та багряно-синюшного відтінку шкірного покриву на рівні стопи, ознак запального процесу) та інструментальних методів обстеження (ультрасонографії та KT-ангіографії магістральних судин). 
Окрім загальноклінічних, інструментальних та лабораторних методів (загальний аналіз крові, МВ фракції креатинфосфокінази (КФК-МВ), тропоніну Т, насичення артеріальної крові киснем $\left(\mathrm{SpO}_{2}\right)$, ЕКГ у 12 стандартних відведеннях тощо), проводили визначення функціонального стану судинного ендотелію за концентрацією ендотеліну-1 (ЕT-1) в плазмі крові (за допомогою імуноферментного набору фірми “Amersham Pharmacia Biotech”) та вмістом стабільних метаболітів NO, які визначали за реакцією з реактивом Гріса [6]. Розрахунок кількості нітритів здійснювали за калібрувальним графіком. Зазначені обстеження проводили в першу добу госпіталізації хворого і повторно безпосередньо після інтервенційного втручання та в динаміці на 10 добу.

Для статистичного аналізу даних використовували пакет прикладних програм STATISTICA (StatSoft, USA, v 6.0). Для оцінки даних використовували непараметричні методи статистики Манна-Уїтні U-тест для порівняння показників у двох групах $(\mathrm{p}<0,05)$.

Результати досліджень та ї обговорення. У вихідному стані (до лікування) клінічні прояви коморбідної патології та лабораторно-інструментальні показники центральної (за величиною фракції викиду) і периферійної гемодинаміки (за рівнем АТ та частотою пульсу) та метаболічного гомеостазу у хворих обох дослідних груп суттєво не відрізнялись. Так, на момент госпіталізації фракція викиду в пацієнтів дослідної групи становила 56,4+1,8 \%, в контролі - 56,7 \%; помірне підвищення систолічного АТ (САТ) - 140-160 мм рт.ст. та діастолічного АТ (ДАТ) понад 90 мм рт. ст. виявлено у 23 (67,6 \%) хворих дослідної групи та у 13 (65,0 \%) обстежених групи контролю. Порушення показників ліпідного та вуглеводного обміну проявились підвищенням рівня ЗХС, ХС ЛПНЩ, ТГ і глюкози (відповідно 8,2 та 8,3 ммоль/л) у хворих обох дослідних груп. Після інтервенційного лікування в пацієнтів дослідної групи, до комплексного лікування яких включено аргінін-карнітиновий комплекс, показники фракції викиду зросли на 1,3 \%, а САТ і ДАТ знизилися на 13,2 та 10,4 \% відповідно. Одночасно у цих хворих додатково суттєво зменшувався вміст ЗХС, ХС ЛПНЩ, ТГ та глюкози - на 22,5, 32,3, 35,5 і 19,5 \% відповідно та, як було показано раніше, відновлювалася рівновага в функціонуванні прооксидантно-антиоксидантної системи.

Аналіз структуру та частоту ускладнень в обстежених групах хворих безпосередньо після проведеної ургентної ангіопластики та стентуван- ня інфаркт-залежної коронарної артерії показав, що в пацієнтів дослідної групи, яким у комплексне медикаментозне лікування додатково призначали курс терапії аргінін-карнітиновим комплексом, такі ускладнення, як тромбендокардит лівого шлуночка, кардіогенний шок, набряк легень, розрив вільної стінки лівого шлуночка, міжшлуночкової перегородки, відрив сосочкових м'язів взагалі не зафіксовані.

Одночасно зауважимо, що у хворих на ГКСбпST із коморбідним облітеруючим атеросклерозом та критичною ішемією нижніх кінцівок у післяопераційному періоді (після ЧКВ) найчастіше розвивався реперфузійний синдром із різною тривалістю та виразністю лівошлуночкової недостатності та порушень ритму і провідності (рис. 1). За даними рисунка 1 , у вихідному стані безпосередньо після проведеного операційного втручання (ЧКВ) у хворих на ГКСбпSТ у поєднанні з ОАНК дослідної групи достовірно знижувалась частота розвитку таких порушень, як суправентрикулярна та шлуночкова екстрасистолія, атріовентрикулярні блокади (Р>0,05).

Гостра лівошлуночкова недостатність (ГСН) супроводжувала перебіг даної коморбідної патології в усіх хворих обох груп, проте ГСН II і III ФК за Killip et Kimball (1972) безпосередньо після інвазивного коронарного втручання спостерігали частіше у пацієнтів контрольної групи, тоді як у хворих дослідної групи ГСН не перевищувала II ФК. Досягнутий кращий клінічний ефект безпосередньо після інвазивного втручання у хворих дослідної групи підтверджував ефективність застосування аргінін-карнітинового комплексу і обгрунтовував доцільність продовження курсу лікування в післяопераційному періоді.

При цьому зауважимо, що одним із тригерів у розвитку реперфузійного синдрому при даній коморбідній патології вважають надходження в ішемізовані тканини кисню. Водночас розвивається невідповідність між кількістю кисню в артеріальній крові й можливостями реоксигенованих тканин його утилізувати. Обидва вказані процеси тісно пов'язані $з$ кисневотранспортною функцією крові, прооксидантно-антиоксидантною рівновагою та станом ендотеліальної функції мікросудин [12]. Наведені дані спонукали до дослідження можливості корекції ендотеліальної дисфункції у хворих ГКСбпSТ в поєднанні з ОАНК та критичною ішемією міокарда та нижніх кінцівок такими фізіологічними метаболічними препаратами, як L-карнітин та L-аргінін.

При цьому встановлено, що у вихідному стані показники функціонального стану ендотелію у всіх 


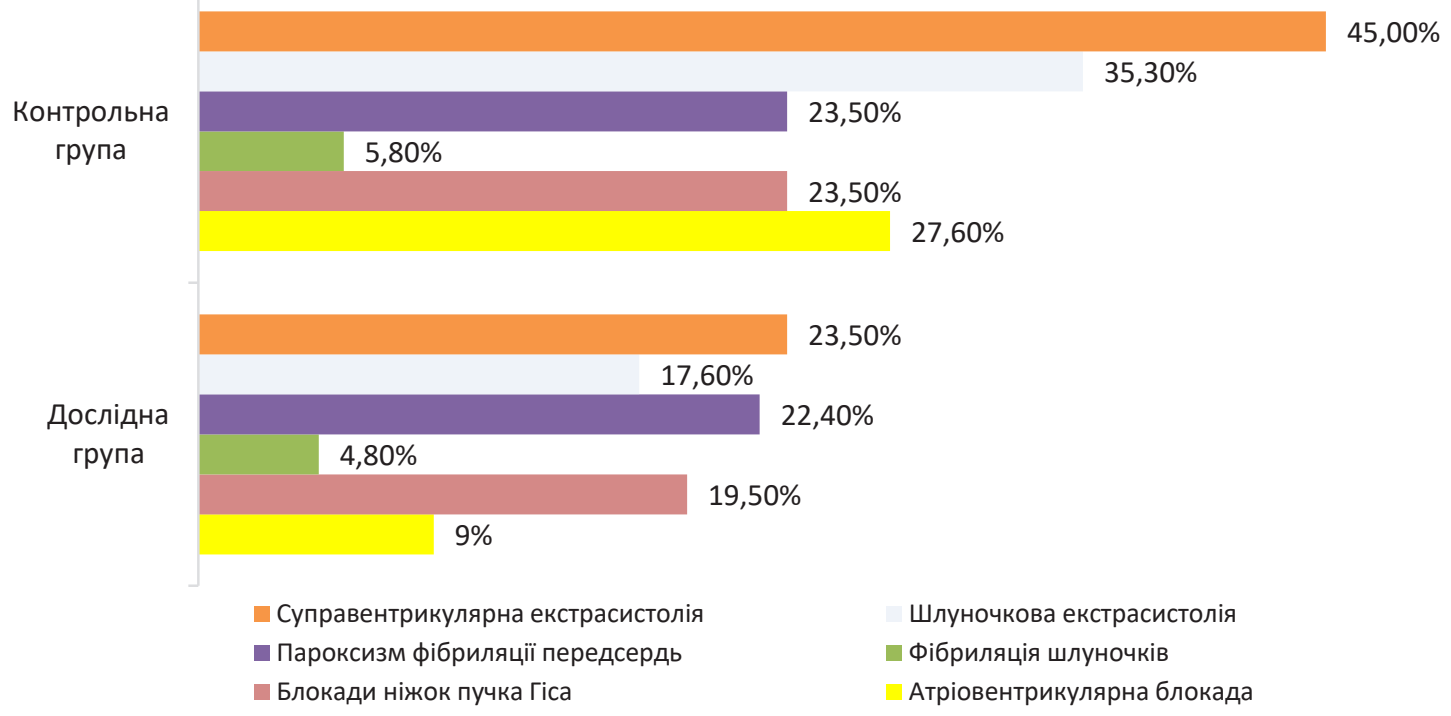

Рис. 1. Частота розвитку порушень ритму та провідності у хворих на ГКСбпSТ у поєднанні з ОАНК дослідної і контрольної груп безпосередньо після інвазивного втручання (ЧКВ).

хворих на ГКСбпSТ в поєднанні з ОАНК та критичною ішемією достовірно не відрізнялись між собою, але були суттєво порушені порівняно з референтними даними (табл. 1), що може свідчити про виражене порушення мікроциркуляції у цих паці- єнтів. Так, рівень ендотеліну-1 у вихідному стані у хворих на ГКСбпSТ у поєднанні з ОАНК зростав на 47,4 \%, а концентрація нітратів та нітритів знижувалась майже в 2 рази порівняно зі значеннями у здорових осіб. В процесі лікування у пацієн-

Таблиця 1. Динаміка показників ендотеліальної функції судин у хворих на ГКСбпST у поєднанні з ОАНК

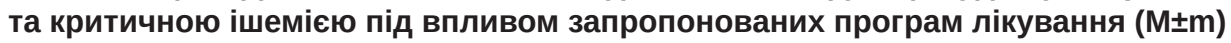

\begin{tabular}{|c|c|c|c|c|c|c|c|}
\hline \multicolumn{2}{|l|}{ Показники } & До лікування & 1 день лікування & 10 днів лікування & P1 & P2 & P3 \\
\hline \multirow[t]{3}{*}{ Ендотелін-1, нг/мл } & 1 & $0,46 \pm 0,03$ & & & & & \\
\hline & 2 & $\underline{0,97 \pm 0,03}$ & $\underline{0,78 \pm 0,03}$ & $\underline{0,64 \pm 0,05}$ & $<0,05$ & $<0,05$ & $<0,05$ \\
\hline & 3 & $\underline{0,97 \pm 0,05}$ & $\underline{0,107 \pm 0,05}$ & $\underline{0,85 \pm 0,04}$ & $>0,05$ & $<0,05$ & \\
\hline \multirow[t]{3}{*}{$\mathrm{NO}_{2}$, мкмоль/л } & 1 & $11,46 \pm 0,34$ & & & & & \\
\hline & 2 & $\underline{5,69 \pm 0,42}$ & $\underline{6,21 \pm 0,42}$ & $\underline{7,85 \pm 0,39}$ & $>0,05$ & $<0,05$ & $<0,05$ \\
\hline & 3 & $\underline{5,66 \pm 0,43}$ & $\underline{5,18 \pm 0,43}$ & $\underline{6,71 \pm 0,32}$ & $>0,05$ & $<0,05$ & \\
\hline \multirow[t]{3}{*}{$\mathrm{NO}_{3}$, мкмоль/л } & 1 & $25,46 \pm 0,53$ & & & & & \\
\hline & 2 & $\underline{12,86 \pm 0,46}$ & $\underline{14,67 \pm 0,46}$ & $\underline{18,89 \pm 0,51}$ & $<0,05$ & $<0,05$ & $>0,05$ \\
\hline & 3 & $\underline{13,08 \pm 0,43}$ & $\underline{13,47 \pm 0,43}$ & $\underline{18,70 \pm 0,42}$ & $>0,05$ & $<0,05$ & \\
\hline \multirow[t]{3}{*}{ NOع, мкмоль/л } & 1 & $36,92 \pm 0,37$ & & & & & \\
\hline & 2 & $\underline{17,75 \pm 0,42}$ & $\underline{19,79 \pm 0,42}$ & $\underline{28,74 \pm 0,52}$ & $<0,05$ & $<0,05$ & $<0,05$ \\
\hline & 3 & $\underline{18,37 \pm 0,42}$ & $\underline{18,07 \pm 0,42}$ & $\underline{24,45 \pm 0,52}$ & $>0,05$ & $<0,05$ & \\
\hline
\end{tabular}

Примітки: 1.2 _ - відповідно показники у здорових, у дослідній групі хворих та в групі контролю;

2. P1, P2, Р3 - відповідно достовірність різниці між параметрами до лікування та у 1-й день, у 1 та 10 день лікування та

на 10 день лікування між дослідною та контрольною групами.

3. Підкреслені показники достовірно відрізняються від відповідних групи здорових осіб. 
тів контрольної групи, яким проводили лише протокольне медикаментозне лікування без додавання цитопротекторної терапії, безпосередньо після операційного втручання (ЧКВ) рівень ендотеліну-1 та метаболітів оксиду азоту суттєво не змінювалися або навіть зростали $(\mathrm{P}<0,05)$. Водночас у хворих дослідної групи, яким після інтервенційного втручання на коронарних судинах у комплексне лікування додатково включали терапію L-аргініном та L-карнітином, вже через добу лікування активність ET-1 та концентрація нітритів в сироватці крові суттєво знижувались $(\mathrm{P}<0,05)$. Тобто дане лікування сприяло відновленню ендотеліальної функції мікросудин і запобігало розвитку реперфузійного синдрому у вигляді серцевої недостатності та реперфузійних аритмій у хворих на ГКСбпST у поєднанні з ОАНК та критичною ішемією.

Особливо відчутного клініко-лабораторного ефекту запропонованого комплексного лікування досягнуто після завершення курсу терапії. Так, через 10 днів під впливом застосування комплексної медикаментозної терапії з включенням аргінінкарнітинового комплексу у пацієнтів дослідної групи суттєво знижувався рівень ендотеліну-1 та зростала концентрація нітритів і нітратів у плазмі крові $(\mathrm{P}<0,05)$ і в більшості пацієнтів їх рівень після завершення стаціонарного етапу комплексного медикаментозного лікування досягав референтної норми. При цьому зауважимо, що загальновживане протокольне лікування не забезпечувало повного відновлення ендотеліальної функції судин у контрольній групі пацієнтів з ГКСбпST у поєднанні з ОАНК та критичною ішемією, загальна концентрація метаболітів оксиду азоту в плазмі крові у них була на 19 \% нижча від референтного показника $(\mathrm{P}<0,05)$.

Таким чином, отримані результати комплексного дослідження клініко-функціонального стану хворих на ГКСбпSТ у поєднанні з ОАНК та критичною ішемією дають можливість зробити висновок, що у цих коморбідних пацієнтів методом вибору лікування є ургентне інтервенційне втручання, коронарна ангіопластика та стентування інфаркт-залежної коронарної артерії. Разом із тим, наявність у хворих виражених порушень мікроциркуляції та ендотеліальної функції у вихідному стані та їхнє додаткове погіршення в пери- та післяопераційному періоді після перкутанного коронарного втручання часто супроводжується розвитком реперфузійного синдрому з різною тривалістю та виразністю лівошлуночкової недостатності та порушень ритму і провідності. Під впливом стандартного медикаментозного лікування у хворих контрольної групи встановлено наявність ре- зистентних до лікування суправентрикулярних та шлуночкових екстрасистол, що обгрунтовувало застосування додаткової антиаритмічної терапії. Водночас у хворих на ГКСбпST у поєднанні з ОАНК дослідної групи під впливом комплексного медикаментозного лікування з включенням L-аргініну та L-карнітину вже на другу добу спостереження встановлено суттєве зменшення частоти порушень ритму і провідності. Після завершення курсу лікування у даних коморбідних хворих дослідної групи частота порушень ритму i провідності знизилась на 53,1 \%, а прояви гострої серцевої недостатності на 44,2 \%.

Отриманий позитивний результат впливу запропонованого лікування на інотропну функцію серця та достовірне зниження частоти і вираженості реперфузійних аритмій, на нашу думку, досягнуто саме за рахунок кардіометаболічного впливу L-карнітину, який за даними багатьох дослідників відіграє важливу роль в енергетичному обміні в міокарді за рахунок перенесення вільних жирних кислот із цитозолю всередину мітохондрій і тим самим забезпечує біодоступність високоенергетичного субстрату для окисного метаболізму в кардіоміоциті [9, 11]. Крім того, полегшуючи оксидацію довголанцюгових жирних кислот та модулюючи співвідношення KoA до KoA-SH, сполука бере участь у зв’язуванні ацильних залишків у пероксисомах і мітохондріях та позитивно впливає на обмін амінокислот, асимілюючи масив вільнорадикальних сполук, що забезпечує стабілізацію органел і клітинних мембран та запобігає накопиченню в цитоплазмі кардіоміоцитів ефірів жирних кислот, які можуть призводити до виникнення фатальних шлуночкових аритмій.

У процесі дослідження було також встановлено виражений вплив даного лікування на показники функціонального стану ендотелію у хворих на ГКСбпST у поєднанні з OAHK та критичною ішемією. Тобто таке комплексне лікування сприяло швидкому і повному відновленню ендотеліальної функції судин, що можна пояснити застосуванням L-аргініну, який проявляє себе як активний регулятор проміжного обміну і процесів енергозабезпечення [4] та є основним субстратом для синтезу оксиду азоту, основною фізіологічною роллю якого є регуляція функціонального стану ендотелію судин і забезпечення відповідного рівня мікроциркуляції органів і тканин організму [13]. Більше того, в багатьох дослідженнях було продемонстровано, що застосування L-аргініну після проведення стентування зменшувало число рестенозів [4] завдяки його антигіпоксичній, антиоксидантній та мембраностабілізуючій активності. 
У цілому можна зробити висновок, що запропонована методика профілактики реперфузійних ускладнень у коморбідних хворих на ГКС у поєднанні з критичною ішемією нижніх кінцівок та високим операційним і післяопераційним ризиком шляхом курсового використання аргінін-карнітинового комплексу показала достатній клінічний ефект завдяки патогенетичному впливу на наявні у таких пацієнтів порушення вільнорадикального окиснення, ендотеліальної функції мікросудин, які супроводжуються зниженням скоротливої функції міокарда, розвитком фатальних аритмій та реперфузійних ускладнень. Отриманий результат обгрунтовує доцільність впровадження запропонованої цитопротекторної антиоксидантної терапії в передопераційному періоді для запобігання проявам реперфузійного синдрому та iï продовження в післяопераційному періоді для стабілізації клінічного стану пацієнтів та вторинної профілактики ускладнень.

Висновки. 1. У хворих на ГКСбпSТ у поєднанні з облітеруючим атеросклерозом та критичною ішемією нижніх кінцівок у вихідному стані спостерігаються виражені порушення ендотеліальної дисфункції судин, що проявляється досто- вірним підвищенням у сироватці крові рівня ендотеліну-1, зниженням концентрації нітритів і нітратів $(\mathrm{P}<0,05)$ та розвитком синдрому серцевої недостатності та порушень ритму і провідності.

2. Метаболічні зміни та наявність у таких коморбідних хворих виражених порушень ендотеліальної функції мікросудин у вихідному стані та їхнє додаткове погіршення в пери- та післяопераційному періодах після перкутанного коронарного втручання часто супроводжується розвитком реперфузійного синдрому з різною тривалістю та виразністю лівошлуночкової недостатності та порушень ритму і провідності.

3. Застосування курсу комплексної медикаментозної терапії з включенням L-аргініну та L-карнітину в перед- та післяопераційний періоди у хворих на ГКСбпSТ у поєднанні з облітеруючим атеросклерозом та критичною ішемією нижніх кінцівок і високим операційним ризиком приводило до відновлення ендотеліальної функції судин і достовірного покращення параметрів центральної та периферичної кардіогемодинаміки, що супроводжувалось зменшенням частоти розвитку та вираженості таких ускладнень, як реперфузійні аритмії (на 53,1 \%) та лівошлуночкова недостатність (на 44,2 \%).

\section{СПИСОК ЛІТЕРАТУРИ}

1. Гандзюк В. А. Динаміка захворюваності і смертності внаслідок хвороб системи ковообігу в Україні (регіональний аспект) / В. А. Гандзюк, Д. Д. Дячук, Н. Ю. Кондратюк // Вісник проблем біол. і мед. - 2017. - № 2 (136). - С. 319-322.

2. Геник С. М. Реперфузійний синдром після реваскуляризації ішемії нижніх кінцівок / С. М. Геник, А. В. Симчич // Серце і судини. - 2016. - № 3. - С. 104-108.

3. Горобець Н. М. Нові стратегічні підходи до корекції ендотеліальної дисфункції / Н. М. Горобець // Ліки України. 2015. - № 2 (188). - С. 20-24.

4. Григорьев А. М. Факторы риска неблагоприятных исходов коронарного шунтирования у пациентов с изолированным и мультифокальным атеросклерозом : автореф. дисс. на соискание науч. степени канд. мед. наук / А. М. Григорьев. - Кемерово, 2014. - 21 с.

5. Коваленко В. М. Кардіологія в Україні: вчора, сьогодні і в майбутньому / В. М. Коваленко // Укр. кардіол. журнал. 2015. - № 2. - C. 9-16.

6. Кондаков І. Л. Способи морфо-функціонального дослідження стану ендотелію: метод. рек. / І. Л. Кондаков, А. Ф. Яковенко. - Харків, 2000. - 18 с.

7. Особенности кардиореабилитации и коррекции нарушений систоло-диастолической функции и вариабельности ритма сердца у больных острым коронарным синдромом с реваскуляризацией коронарных артерий / М. И. Швед, Л. В. Цуглевич, И. Б. Киричок [и др.] // Georgian Med. News. - 2017. - № 4 (265). - С. 46-53.

8. Распространенность и клиническая значимость мультифокального атеросклероза у пациентов с ишемической болез-

нью сердца / О. Л. Барбараш, М. В. Зыков, В. В. Кашталап, Л. С. Барбараш // Кардиология. - 2011. - Т. 51, № 8. - С. 66-71. 9. Astashkin E. I. Role of L-carnitine in energy metabolism cardiomyocytes and treatment of diseases of cardiovascular system / E. I. Astashkin, M. G. Glezer // Cardiol. Cardiovasc. Surg. - 2012. - Vol. 6 (2). - P. 58-65.

10. Critical limb ischemia: current trends and future directions / M. S. Conte, F. L. Moll, M. C. Verhaar, M. Teraa // J. Am. Heart Assoc. - 2016. - Vol. 5. - e002938.

11. DiNicolantonio J. L-carnitine in the secondary prevention of cardiovascular disease: Systematic revien and meta-analysis / J. DiNicolantonio, C. Lavie, H. Fares // Mayo Clin. Proc. - 2013. - Vol. 88 (6). - P. 544-551.

12. Fakhry F. Endovascular revascularization and supervised exercise for peripheral artery disease and intermittent claudication: a randomized clinical trial / F. Fakhry, S. Spronk, L. van der Laan // JAMA. - 2015. - Vol. 314. - P. 1936-1944.

13. L-arginine attenuates lymphocyte activation and antioxidized LDL antibody levels in patients undergoing angioplasty / J. George, S. B. Shmuel, A. Roth [et al.] // Atherosclerosis. 2004. - Vol. 174 (2). - P. 323-327.

14. Evolocumab and clinical outcomes in patients with cardiovascular disease / M. S. Sabatine, R. P. Giugliano, A. C. Keech [et al.] // N. Engl. J. Med. - 2017. - Vol. 376 (18). P. $1713-1722$.

15. Trends in mortality from cardiovascular and cerebrovascular diseases in Europe and other areas of the world / F. Levi, F. Luccbini, E. Negri, C. La Veccbia // Heart. - 2002. - Vol. 88, No. 2. - P. 119-124. 


\section{REFERENCES}

1. Handziuk, V.A., Diachuk, D.D., \& Kondratiuk, N.Yu. (2017). Dynamika zakhvoriuvanosti i smertnosti vnaslidok khvorob systemy kovoobihu v Ukraini (rehionalnyi aspekt) [Dynamics of morbidity and mortality due to diseases of the circulatory system in Ukraine (regional aspect)]. Visnyk problem biol. i med. - Bulletin of Problems of Biology and Medicine, 2 (136), 319-322 [in Ukrainian].

2. Genyk, S.M., \& Simchich, A.V. (2016). Reperfuziinyi syndrom pislia revaskuliaryzatsii ishemii nyzhnikh kintsivok [Reperfusion syndrome after revascularization of the ischemic lower limbs]. Sertse i sudyny - Heart and Vessels, 3, 104-108 [in Ukrainian].

3. Horobets, N.M. (2015). Novi stratehichni pidkhody do korektsii endotelialnoi dysfunktsii [New strategic approaches to the correction of endothelial dysfunction]. Liky Ukrainy - Medicine of Ukraine, 2 (188), 20-24 [in Ukrainian].

4. Grigoryev, A.M. (2014). Faktory riska neblagopriyatnykh iskhodov koronarnogo shuntirovaniya u patsiyentov s izolirovannym i multifokalnym aterosklerozom [Risk factors for adverse outcomes of coronary bypass grafting in patients with isolated and multifocal atherosclerosis]. Extended abstract of Candidate's thesis. Kemerovo [in Russian].

5. Kovalenko, V.M. (2015). Kardiolohiia v Ukraini: vchora, siohodni i v maibutniomu [Cardiology in Ukraine: yesterday, today and in the future]. Ukr. kardiol. zhurnal - Ukrainian Journal of Cardiology, 2, 9-16 [in Ukrainian].

6. Kondakov, I.L., \& Yakovenko, A.F. (2000). Sposoby morfofunktsionalnoho doslidzhennia stanu endoteliiu: metod. rek. [Methods of morpho-functional study of the endothelium: guidelines]. Kharkiv [in Ukrainian].

7. Shved, M.I., Tsuglevich, L.V., Kirichok, I.B., Levitskaya, L.V., Boyko, T.V., \& Kitsak, Ya.M. (2017). Osobennosti kardioreabilitatsii i korrektsii narusheniy sistolo-diastolicheskoy funktsii i variabelnosti ritma serdtsa u bolnykh ostrym koronarnym sindromom s revaskulyarizatsiyey koronarnykh arteriy [Car- dioreabilitation peculiarities and correction of violations of systolic, diastolic function and heart ratevariability in patients with acute coronary sundrome and coronary artery revascularization]. Georgian Med. News, 4 (265), 46-53 [in Russian].

8. Barbarash, O.L., Zykov, M.V., Kashtalap, V.V., \& Barbarash, L.S. (2011). Rasprostranennost i klinicheskaya znachimost multifokalnogo ateroskleroza u patsiyentov s ishemicheskoy boleznyu serdtsa [The prevalence and clinical significance of multifocal atherosclerosis in patients with ischemic heart disease]. Kardiologiya - Cardiology, 51, 8, 66-71 [in Russian].

9. Astashkin, E.I., \& Glezer, M.G. (2012). Role of L-carnitine in energy metabolism cardiomyocytes and treatment of diseases of cardiovascular system. Cardiol. Cardiovasc. Surg., 6 (2), 58-65. 10. Conte, M.S., Moll, F.L., Verhaar, M.C., \& Teraa, M. (2016). Critical limb ischemia: current trends and future directions. J. Am. Heart Assoc., 5, e002938.

11. DiNicolantonio, J., Lavie, C., \& Fares, H. (2013). L-carnitine in the secondary prevention of cardiovascular disease: Systematic revien and meta-analysis. Mayo Clin. Proc., 88 (6), 544-551. 12. Fakhry, F., Spronk, S., \& van der Laan, L. (2015). Endovascular revascularization and supervised exercise for peripheral artery disease and intermittent claudication: a randomized clinical trial. JAMA, 314, 1936-1944.

13. George, J., Shmuel, S.B., Roth, A., Herz, I., Izraelov, S., Deutsch, V., ..., \& Miller, H. (2004). L-arginine attenuates lymphocyte activation and antioxidized LDL antibody levels in patients undergoing angioplasty. Atherosclerosis, 174 (2), 323-327. 14. Sabatine, M.S., Giugliano, R.P., Keech, A.C., Honarpour, N., Wiviott, S.D., Murphy, S.A., ..., \& Pedersen, T.R. (2017). Evolocumab and clinical outcomes in patients with cardiovascular disease. N. Engl. J. Med., 376 (18), 1713-1722.

15. Levi, F., Luccbini, F., Negri, E., \& La Veccbia, C. (2002). Trends in mortality from cardiovascular and cerebrovascular diseases in Europe and other areas of the world. Heart, 88, 2, 119-124.

Отримано 27.01.2021

Електронна адреса для листування: shvedmukola@ukr.net

I. K. VENGER, T. O. DOBRIANSKIY, M. I. SHVED

I. Horbachevsky Ternopil National Medical University

\section{CLINICAL EFFICACY IN CORRECTION OF VESSELS' ENDOTHELIAL DYSFUNCTION IN THE PERI- AND POSTOPERATIVE PERIOD IN PATIENTS WITH ACUTE CORONARY SYNDROME IN COMBINATION WITH OBLITERATING ATHEROSCLEROSIS OF THE LOWER EXTREMITIES}

\footnotetext{
The aim of the work: to study the effectiveness of interventional and drug treatment of patients with acute coronary syndrome without ST segment elevation in combination with obliterating atherosclerosis of the main vessels at the stage of critical lower extremity ischemia and high risk of cardiac complications at the inpatient stage.

Materials and Methods. The study included 54 patients with acute coronary syndrome without ST elevation in combination with obliterating atherosclerosis stage III-IV of chronic ischemia according to the classification of B. V. Pokrovsky or Fontaine, which corresponds to critical ischemia of the 4th, 5th or 6th categories (grade II-III) according to Rutherford (ESC, 2017). According to the chosen treatment tactics all patients were divided into 2 groups: 34 patients of the main experimental group in addition to standard corticosteroid treatment, received an additional intravenous $4.2 \mathrm{~g}$ of L-arginine and $2.0 \mathrm{~g}$ of L-carnitine in the form of a solution for infusion of $100 \mathrm{ml}$ once a day for 7 days. One infusion of the drug was performed before the intervention. The control group included 20 patients who also underwent emergency balloon angioplasty and stenting of the infarct-dependent coronary artery, but patients in this group received only standard protocol treatment.

In addition to general clinical, instrumental and laboratory methods (general blood test, MB fraction of creatine phosphokinase (CPK$\mathrm{MB})$, troponin $\mathrm{T}$, arterial blood oxygen saturation $\left(\mathrm{SpO}_{2}\right)$, ECG in 12 standard leads, etc.), the functional state of vascular endothelium
} 
was determined by endothelin-1 concentration (ET-1) in blood plasma (using an enzyme-linked immunosorbent assay from Amersham Pharmacia Biotech) and the content of stable NO metabolites, which were determined by reaction with Gris reagent.

Results and Discussion. In the initial state in patients with ACS without ST segment elevation in combination with obliterating atherosclerosis of the lower extremity vessels was found the severe disorders of microcirculation and endothelial function and their additional aggravation in the peri- and postoperative periods after percutaneous coronary intervention. It was accompanied by the development of reperfusion syndrome with varying duration and severity of the left ventricular failure and arrhythmias. In patients of the control group under the influence of standard drug treatment was noted the presence of treatment-resistant supraventricular and ventricular extrasystoles. At the same time in patients of the experimental group with ACS without ST segment elevation in combination with obliterating atherosclerosis of the lower extremity vessels under the influence of complex drug treatment with the inclusion of L-arginine and Lcarnitine from the second day of observation was a significant decrease of the frequency of rhythm and conduction disorders. At the end of treatment in comorbid patients of the experimental group the frequency of arrhythmias and conduction decreased by $53.1 \%$ and manifestations of acute heart failure - by $44.2 \%$.

The obtained result substantiates the expediency of introducing the proposed cytoprotective antioxidant therapy in the preoperative period to prevent the manifestations of reperfusion syndrome and its continuation in the postoperative period to stabilize the clinical condition of patients and secondary prevention of complications.

Key words: acute coronary syndrome; obliterating atherosclerosis of the lower extremities, endothelin; nitric oxide; due to cutaneous coronary intervention; reperfusion complications; arginine-carnitine complex.

\section{И. К. ВЕНГЕР, Т. О. ДОБРЯНСКИЙ, Н. И. ШВЕД}

Тернопольский национальный медицинский университет имени И. Я. Горбачевского Моз Украины

\section{КЛИНИЧЕСКАЯ ЭФФЕКТИВНОСТЬ КОРРЕКЦИИ ЭНДОТЕЛИАЛЬНОЙ ДИСФУНКЦИИ СОСУДОВ В ПЕРИ- И ПОС.ЛЕОПЕРАЦИОННОМ ПЕРИОДЕ У ПАЦИЕНТОВ С ОСТРЫМ КОРОНАРНЫМ СИНДРОМОМ В СОЧЕТАНИИ С ОБЛИТЕРИРУЮЩИМ АТЕРОСКЛЕРОЗОМ НИЖНИХ КОНЕЧНОСТЕЙ}

Цель работы: изучить эффективность интервенционого и медикаментозного лечения больных острым коронарным синдромом без подъема сегмента ST в сочетании с облитерирующим атеросклерозом магистральных сосудов на стадии критической ишемии нижних конечностей и высоким риском развития кардиальных осложнений на стационарном этапе лечения.

Материалы и методы. В исследование отобраны 54 больных острым коронарным синдромом без подъема ST в сочетании с облитерирующим атеросклерозом с III-IV стадиями хронической ишемии по классификации Б. В. Покровского или Fontaine, что соответствует критической ишемии 4, 5 и 6 категорий (grade II-III) по Rutherford (ESC, 2017), которых в зависимости от выбранной тактики лечения распределили в 2 группы: основная исследовательская группа - 34 больных, которые, помимо стандартного лечения OKC, дополнительно внутривенно получили 4,2 г L-аргинина и 2,0 г L- карнитина в форме раствора для инфузий 100 мл один раз в сутки курсом 7 дней. Одно вливание препарата проводили перед интервенционным вмешательством. Контрольная группа - 20 пациентов, которым также проведено ургентную баллонную ангиопластику и стентирование инфаркт-зависимой коронарной артерии, но больные этой группы получали только стандартное протокольное лечение.

Кроме общеклинических, инструментальных и лабораторных методов (общий анализ крови, МВ фракции КФК (КФК-МВ), тропонина T, насыщения артериальной крови кислородом (SpO2), ЭКГ в 12 стандартных отведениях и т.д.), проводили определение функционального состояния сосудистого эндотелия по концентрации ендотелина-1 (ЭТ-1) в плазме крови (с помощью иммуноферментного набора фирмы “Amersham Pharmacia Biotech”) и содержанием стабильных метаболитов NO, которые определяли по реакции с реактивом Гриса.

Результаты исследований и их обсуждение. В исходном состоянии у больных ОКСбпST в сочетании с облитерирующим атеросклерозом нижних конечностей установлено выраженные нарушения микроциркуляции и эндотелиальной функции и их дополнительное ухудшение в пери- и послеоперационном периодах после перкутанного коронарного вмешательства, что сопровождается развитием реперфузионного синдрома с разной продолжительностью и выразительностью левожелудочковой недостаточности и нарушений ритма и проводимости. Под влиянием стандартного медикаментозного лечения у больных контрольной группы отмечено наличие резистентных к лечению суправентрикулярных и желудочковых экстрасистол. В то же время у больных ОКСбпST в сочетании с облитерирующим атеросклерозом нижних конечностей основной группы под влиянием комплексного медикаментозного лечения с включением L-аргинина и L-карнитина уже на вторые сутки наблюдения отмечено существенное уменьшение частоты нарушений ритма и проводимости, а при завершении курса лечения у коморбидных больных основной группы частота нарушений ритма и проводимости снизилась на 53,1 \% и проявлений острой сердечной недостаточности на 44,2\%.

Полученный результат обосновывает целесообразность внедрения предложенной цитопротективной антиоксидантной терапии в передоперационном периоде для предупреждения проявлений реперфузионного синдрома и ее продолжение в послеоперационном периоде для стабилизации клинического состояния пациентов и вторичной профилактики осложнений.

Ключевые слова: острый коронарный синдром; облитерирующий атеросклероз нижних конечностей; эндотелин; оксид азота, черезкожное коронарное вмешательство; реперфузионные осложнения; аргинин-карнитиновий комплекс. 